\title{
Improvement of economic-legal support of the digital economy in Russia and Volgograd region
}

\author{
Evgeniya Simaeva \\ Financial University under the Government of the Russian \\ Federation \\ Department of Legal Regulation of Economic Activities \\ Moscow, Russia \\ epsimaeva@fa.ru
}

\author{
Nataliya Simaeva \\ Volgograd State University \\ Institute of Economics and Finance \\ Volgograd, Russia \\ n.simaeva@volsu.ru
}

\author{
Igor Tyutyunnik \\ Financial University under the Government of the Russian Federation \\ Institute of Industrial Policy and Institutional Development \\ Moscow, Russia \\ cpikfa@mail.ru
}

\begin{abstract}
The article substantiates the expediency of improving the economic and legal regulation of the digital economy both at the federal and regional levels, in particular in the Volgograd region. The having system of standard regulation of digital economy in the form of a subordinate legal regulation is defined. Significant gaps in the economic and legal support of the digital economy have been identified and practical recommendations have been proposed for their elimination through the adoption of a federal law "On the implementation of the digital economy in the Russian Federation", changes in civil and tax legislation, the development of a regional program for the Volgograd region of the development of the digital economy until 2024. The comparative and legal analysis of standard and legal regulation of digital economy in foreign countries (United Kingdom, USA) is carried out. The need for legal regulation of the expansion of citizens' access to digital technologies has been established. The legal package for the development of economic and legal support of the digital economy in the Russian Federation, in general, and the Volgograd region in particular, is proposed.
\end{abstract}

Keywords- digital economy, regional legislation, digital infrastructure, digitalization, economic-legal support

\section{INTRODUCTION}

In the conditions of expanding the Internet space and the development of digital technologies, the digital economy and its main directions, including in the financial sector, acquire special relevance in the Russian Federation and regions. In addition, the digital economy is designated as the main theme of the Moscow International Forum "Open Innovations", which took place on Oct. 16-18, 2017 in Skolkovo
Technopark, and on February 8, 2018, the first Digital Transformation Forum took place within the Russian Business Week of the Russian Union of Industrialists and entrepreneurs, which gathered more than 250 best professionals from government and business structures.

In July 2017, the Government of the Russian Federation approved the program "Digital Economy". The digital economy, in accordance with the "Strategy for the Development of the Information Society in the Russian Federation for 2017-2030", is defined as an economic activity in which the key factor in production is data in digital form, processing large volumes and using analysis results in comparison with traditional forms of management can significantly improve the effectiveness of various types of production, technology, equipment, storage, sale, delivery of goods and services [1]. In other words, the digital economy is an activity directly related to the development of digital computer technologies, which includes both services for the provision of online services, and electronic payments, and Internet trading, and crowdfunding and so on.

As the development of information technology, the whole world turns to digital format. In parallel, digitalization changes the daily life of people, the environment. In this regard, the implementation of projects is becoming more urgent: "Smart Region", "Smart City", - an environment based on the interaction of people and computer systems that allows to find and implement a new technological solution in the financial sphere, providing comfort and harmony in the life of citizens, living in large regional centers, such as the Volgograd Region.

In general, the cost of creating a digital infrastructure in the next three years (2017-2020) will amount to 427 billion rubles. Of these, a large share - 328.5 billion rubles - will be 
for extrabudgetary funds and only 98.6 billion rubles for the budget [2].

The key term of the new economy is the "digital platform" - it is a high-tech business model that generates profit by exchanging between independent groups of participants [3].

The main obstacle to the implementation of the directions for the development of the digital economy, including: personnel and education; formation of research competences and technological reserves; information infrastructure; information security - is the lack of legislative support, as well as the mechanism of economic and legal regulation of relations in the field of digital infrastructure.

In this regard, it is necessary to establish at the federal and regional level, the system of economic and legal norms of the complex economic and legal regulation of relations arising in connection with the development of the digital economy, with the result that the regulatory environment in its entirety will provide a favorable legal regime for the emergence and development of modern technologies and economic activities related to the use of digital infrastructure tools.

Thus, the goal of the study is to develop practical recommendations for improving the economic and legal regulation of the digital economy in the Russian Federation and the Volgograd region on the basis of an analysis of problematic issues that hinder the effective regulation of digitalization processes in Russia and the region.

To solve the set goal, it is necessary to solve the problems:

- determine the current system of regulatory and legal regulation of the digital economy of Russia and the Volgograd region;

- identify positive aspects of foreign experience of legal regulation of the digital economy (United Kingdom, USA);

- to assess the main indicators of the development of the digital economy in the Russian Federation and the Volgograd region.

\section{MATERIALS AND Methods (Model)}

The methodology of studying the problems of economic and legal support of the digital economy in Russia and the Volgograd region with the aim of further improving the development of the digital infrastructure is the synthesis of methods of legal science based on materialist dialectics: comparative legal, formal legal, systemic (legal) with an analysis of the main indicators of the development of the digital economy (economic aspect).

The formal-legal (logical) method makes it possible to interpret the normative legal norms of the by-law character that regulate the development of the directions of the digital economy in the Russian Federation and the Volgograd region.
Today, due to lack of legislative regulation of the process of digitalization of the Russian economy, as the main subject of study:

- $\quad$ at the federal level is the program "Digital Economy of the Russian Federation" of July 28, 2017, including the "road map";

- at the regional level - "The Strategy of Social and Economic Development of the Volgograd Region until 2030"; "The Strategy of Social and Economic Development of Volgograd to 2030" dated January 25, 2017 [4].

According to the federal program, the digital economy is represented by three levels that in their close interaction affect the lives of citizens and society as a whole: markets and sectors of the economy (areas of activity) where specific subjects (suppliers and consumers of goods, works and services) interact; platforms and technologies, where competence is formed for the development of markets and industries (spheres of activity); an environment that creates the conditions for the development of platforms and technologies and effective interaction between the subjects of markets and industries (spheres of activity) and covers regulatory regulation, information infrastructure, personnel and information security.

Analyzing the content of the Strategy of socio-economic development of the Volgograd region until 2030 and the Strategy of social and economic development of Volgograd until 2030, it should be noted that neither at the regional nor municipal level, the provisions of the federal program on the development of the main directions of the digital economy have not been continued concretization, which significantly impedes the implementation of the digitalization process in the Volgograd region and requires timely optimization.

The economic aspect of the research is connected, first of all, with the evaluation of indicators of the development of the digital economy.

In 2016, the proportion of residents using broadband Internet access was 18.77 percent. At the same time, there were 159.95 mobile phones per 100 people and 71.29 people out of 100 people used mobile Internet access. The average speed in the Internet in Russia grew by 29 percent (to 12.2 Mbps), which is why Russia is on the same level with France, Italy and Greece [5].

By the beginning of 2017 the Russian market of commercial centers of storage and data processing grew to 14,5 billion rubles, it is 11 percent more, than in 2016 that was in many respects caused by standard requirements about storage of personal data of citizens of Russia in the territory of Russia. However unlike the majority of the countries of Russia has no standards of assessment of the centers of storage and data processing in this connection there is no objective opportunity for assessment of level of the rendered services, including in volume possible for data storage. 
The main indicators of the development of the digital economy, presented in Table 1, indicate a slow growth in the use of the Internet network by the population of the Russian Federation [6]. However, in accordance with the program for the development of the digital economy, by 2024 it is planned to increase the indicators to 97 percent.

TABLE I. MAIN INDICATORS OF DEVELOPMENT OF THE DIGITAL ECONOMY FOR THE PERIOD 2014-2016.

\begin{tabular}{|l|c|c|c|}
\hline \multicolumn{1}{|c|}{ Name of an indicator } & 2014 & 2015 & 2016 \\
\hline $\begin{array}{l}\text { Subscribers of fixed broadband internet per 100 } \\
\text { population, units. }\end{array}$ & 17.0 & 18.3 & 18.7 \\
\hline $\begin{array}{l}\text { Mobile subscribers of fixed broadband internet } \\
\text { per 100 population, units. }\end{array}$ & 64.5 & 68.1 & 72.4 \\
\hline $\begin{array}{l}\text { The share of the population, the public and } \\
\text { municipal services using the Internet for } \\
\text { receiving in an electronic form for the last 12 } \\
\text { months, at the age of } 15-72 \text { years, percent }\end{array}$ & 35 & 40 & 51 \\
\hline $\begin{array}{l}\text { The share of the population, the goods using the } \\
\text { Internet for the order, services for the last 12 } \\
\text { months, at the age of } 15-72 \text { years, percent }\end{array}$ & 18 & 20 & 23 \\
\hline $\begin{array}{l}\text { The share of the population ever using the } \\
\text { Internet at the age of } 15-72 \text { years, percent }\end{array}$ & 74 & 78 & 81 \\
\hline
\end{tabular}

Thus, an increasing number of citizens of the Russian Federation recognize the need for digital competencies, but the level of use of personal computers and the information and telecommunications network "Internet" in Russia is still lower than in Europe. At the same time, there is a serious gap in the digital skills between certain population groups.

\section{RESULTS AND DISCUSSION}

Problems of improvement of economical and legal regulation of the public relations in the sphere of digital economy need to be considered, first of all, through a prism of the normative legal acts regulating bases and the principles of digital economy.

The system of normative and legal digital transformation of various spheres of public life in Russia is represented only at the level of by-laws, among which:

- Decrees of the President of the Russian Federation: "On the Strategy for Economic Security of the Russian Federation for the Period to 2030" dated May 13, 2017 No. 208, "On the Strategy for the Development of the Information Society in the Russian Federation for 2017-2030" dated May 9, 2017 No. 203, "On the Economic Council under the President of the Russian Federation" dated 16.07.2012, No. 1001 (as amended on 03/04/2017), "On the Strategy for Scientific and Technological Development of the Russian Federation" dated 01.12.2016 No. 642 .
- Normative acts of the Government of the Russian Federation: Order of the Government of the Russian Federation On the approval of the program "Digital Economy of the Russian Federation" of July 28, 2012, No. 1632-r, Resolution of the Government of the Russian Federation of 15.08. 2017 No. 969 "On the Subcommission on the Digital Economy", the Government Decree "On the system for managing the implementation of the program" Digital Economy of the Russian Federation "dated August 28, 2017 No. 1030 .

As for foreign experience in the legal regulation of the digital economy, it should be noted the legislative practice of the United Kingdom of Great Britain and the United States of America.

So, in April 2017, according to the official website of the British Parliament by royal sanction entered into force a law on the digital economy (Digital Economy Act 2017). However it is not the first experience of Great Britain in legal support of digital economy. In 2010 the law of the same name - the law on digital economy (Digital Economy Act 2010) in which the aspects of public policy concerning digital mass media stated in "Digital Britain" - the government program aimed at providing positions of Great Britain in the forefront of global digital economy were realized was adopted [7].

Digital Economy Act 2017 regulates questions concerning assistance to consumers in obtaining broadband Internet communications, creating a digital infrastructure, optimizing access for obtaining government services using digital technologies, protecting intellectual property in connection with the use of electronic communications. The Act of 2017 expanded the rights of the supervisory authority in the field of IT communications (Ofcom) to control compliance with copyright, the interests of Internet operators and users of the Internet, and also introduced an update of the Code of Electronic Communications, the specification of digital public services e-government and norms on liability for offenses in the digital environment.

In 2017, the US Senate presented several bills on the digital economy: a bill on the introduction of innovations and the growth of Internet technologies, the launch of universal access to the global economy (DIGITAL CENTURY) (Driving Innovation and Growth in Internet Technology and Launching Universal Access to the Global Economy DIGITAL AGE) Act of 2017) [8], the draft law on the management of copyrights in the field of the digital economy (Copyright Office for the Digital Economy Act) [9].

The first bill is aimed at providing access to mobile and broadband Internet, encouraging investments by international financial institutions and US corporations in projects to expand and connect to the Internet infrastructure, encouraging partner countries to implement policies to reduce prices and improve the quality of Internet services. The second bill establishes the US Copyright Office as a separate independent institution in the legislative branch, headed by a director appointed by the President with the consent of the Senate. 
Currently, the Copyright Office is part of the Library of Congress (LOC) and is headed by the Copyright Register.

Thus, the system of standard regulation of digital economy in foreign countries is directed to increase in access to the population to Internet resources and digital technologies in various spheres, protection of author's rights in digital space and a regulation of restrictions for access to the websites and contents violating human rights and separate categories of citizens.

Next, we will analyze the main indicators of the development of the digital economy of the subjects of the Russian Federation of the Southern Federal District, with the exception of those included in it, in accordance with Presidential Decree No. 375 of July 28, 2016, the Republic of Crimea and Sevastopol, subjects of the Crimean Federal District, abolished in order to increase effectiveness of public authorities.

Based on the analysis of the subjects of the Southern Federal District, including the Volgograd Region (table 2), it should be noted that, in comparison with other regions, the indicators of the use of broadband Internet resources by organizations in 2015 are high. At the same time, estimating the average number of employees in organizations of the IT industry, the Volgograd Region loses significantly in these indicators to the Republic of Kalmykia, the Republic of Adygea, and also the Astrakhan region. Indicators of use of the Internet by the population of the Volgograd region for receiving the public and municipal services in an electronic form are insignificant that testifies to importance of digitalization of the region [10].

The evidence of the need to improve the regulation of the digital economy in the Volgograd region is the data in Table 3, which reflect the level of availability of population use by the region of fixed broadband Internet.
TABLE II. DISTRIBUTION OF THE CENTRAL AND NORTH-WEST FEDERAL DISTRICTS, SUBJECTS OF THE SOUTHERN FEDERAL DISTRICT OF THE RUSSIAN FEDERATION ON THE MAIN INDICATORS OF DEVELOPMENT OF THE DIGITAL ECONOMY

\begin{tabular}{|c|c|c|c|c|c|}
\hline \multirow[b]{2}{*}{$\begin{array}{l}\text { Name of the } \\
\text { region }\end{array}$} & \multicolumn{3}{|c|}{2015} & \multicolumn{2}{|r|}{2016} \\
\hline & $\begin{array}{l}\text { Average } \\
\text { number } \\
\text { of } \\
\text { employee } \\
\text { s in } \\
\text { organizat } \\
\text { ions of } \\
\text { the IT } \\
\text { industry, } \\
\text { thousand } \\
\text { people }\end{array}$ & $\begin{array}{l}\text { Percenta } \\
\text { ge of } \\
\text { organiza } \\
\text { tions } \\
\text { using } \\
\text { broadba } \\
\text { nd } \\
\text { Internet, } \\
\text { percent }\end{array}$ & $\begin{array}{l}\text { Subscribe } \\
\text { rs of } \\
\text { mobile } \\
\text { broadban } \\
\text { d access } \\
\text { to the } \\
\text { Internet } \\
\text { per 100 } \\
\text { people of } \\
\text { the } \\
\text { populatio } \\
\text { n, units. }\end{array}$ & $\begin{array}{l}\text { The } \\
\text { share of } \\
\text { the } \\
\text { populati } \\
\text { on that } \\
\text { ever } \\
\text { used the } \\
\text { Internet, } \\
\text { aged 15- } \\
72 \text { years, } \\
\text { percent }\end{array}$ & $\begin{array}{l}\text { The share of } \\
\text { the } \\
\text { population } \\
\text { using the } \\
\text { Internet for } \\
\text { public } \\
\text { municipal } \\
\text { services in } \\
\text { electronic } \\
\text { form, at the } \\
\text { age of 15-72 } \\
\text { years, } \\
\text { percent }\end{array}$ \\
\hline $\begin{array}{l}\text { Southern } \\
\text { Federal } \\
\text { District }\end{array}$ & 6 & $7-8$ & $3-4$ & $4-6$ & $4-5$ \\
\hline $\begin{array}{l}\text { Republic of } \\
\text { Adygea }\end{array}$ & $74-78$ & $8-10$ & $21-22$ & $79-81$ & $62-63$ \\
\hline $\begin{array}{l}\text { Republic of } \\
\text { Kalmykia }\end{array}$ & $79-82$ & $53-55$ & $30-32$ & $33-39$ & $55-59$ \\
\hline $\begin{array}{l}\text { Krasnodar } \\
\text { region }\end{array}$ & 13 & $56-63$ & 9 & $28-32$ & $27-28$ \\
\hline $\begin{array}{l}\text { Astrakhan } \\
\text { Region }\end{array}$ & $47-54$ & $46-52$ & $19-20$ & $19-27$ & $64-66$ \\
\hline $\begin{array}{l}\text { Volgograd } \\
\text { region }\end{array}$ & $20-23$ & 81 & $45-47$ & $40-45$ & $40-41$ \\
\hline Rostov region & 14 & $46-52$ & $53-54$ & $14-18$ & 18 \\
\hline $\begin{array}{l}\text { Central } \\
\text { Federal } \\
\text { District }\end{array}$ & 1 & 3 & $3-4$ & 3 & 1 \\
\hline Moscow & 1 & 2 & $1-2$ & 5 & 6 \\
\hline $\begin{array}{l}\text { North-West } \\
\text { Federal } \\
\text { District }\end{array}$ & 3 & 2 & $3-4$ & 1 & 7 \\
\hline
\end{tabular}


TABLE III. MAIN INDICATORS OF DEVELOPMENT OF THE DIGITAL ECONOMY IN SUBJECTS OF THE SOUTHERN FEDERAL DISTRICT AND CENTRAL AND NORTH-WEST FEDERAL DISTRICTS OF THE RUSSIAN FEDERATION

\begin{tabular}{|c|c|c|c|c|c|}
\hline \multirow[b]{2}{*}{$\begin{array}{l}\text { Name of the } \\
\text { region }\end{array}$} & \multicolumn{3}{|c|}{2015} & \multicolumn{2}{|c|}{2016} \\
\hline & $\begin{array}{l}\text { Average } \\
\text { number of } \\
\text { employees in } \\
\text { organizations } \\
\text { of the IT } \\
\text { industry, } \\
\text { thousand } \\
\text { people }\end{array}$ & $\begin{array}{l}\text { Percentag } \\
\text { e of of } \\
\text { organizati } \\
\text { ons using } \\
\text { broadband } \\
\text { Internet, } \\
\text { percent }\end{array}$ & 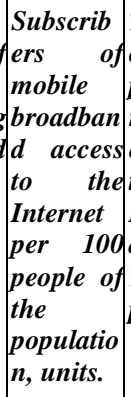 & $\begin{array}{l}\text { The } \text { share } \\
\text { of } \quad \text { the } \\
\text { populatio } \\
n \quad \text { that } \\
\text { ever used } \\
\text { the } \\
\text { Internet, } \\
\text { aged } 15 \\
72 \text { years, } \\
\text { percent }\end{array}$ & $\begin{array}{l}\text { The share } \\
\text { of the } \\
\text { population } \\
\text { using the } \\
\text { Internet for } \\
\text { public } \\
\text { municipal } \\
\text { services in } \\
\text { electronic } \\
\text { form, at the } \\
\text { age of 15-72 } \\
\text { years }\end{array}$ \\
\hline $\begin{array}{l}\text { Southern } \\
\text { Federal District }\end{array}$ & 16,1 & 75 & 72 & 81 & 48 \\
\hline $\begin{array}{l}\text { Republic of } \\
\text { Adygea }\end{array}$ & 0,3 & 88 & 72 & 71 & 35 \\
\hline $\begin{array}{l}\text { Republic of } \\
\text { Kalmykia }\end{array}$ & 0,2 & 78 & 68 & 80 & 38 \\
\hline $\begin{array}{l}\text { Krasnodar } \\
\text { region }\end{array}$ & 5,5 & 77 & 87 & 81 & 52 \\
\hline $\begin{array}{l}\text { Astrakhan } \\
\text { Region }\end{array}$ & 1,3 & 79 & 73 & 82 & 33 \\
\hline $\begin{array}{l}\text { Volgograd } \\
\text { region }\end{array}$ & 3,6 & 64 & 62 & 79 & 45 \\
\hline Rostov region & 5,2 & 79 & 59 & 83 & 57 \\
\hline $\begin{array}{l}\text { Central Federal } \\
\text { District }\end{array}$ & 158,8 & 83 & 79 & 82 & 56 \\
\hline Moscow & 116,5 & 95 & 90 & 89 & 65 \\
\hline $\begin{array}{l}\text { North-West } \\
\text { Federal District }\end{array}$ & 55,5 & 85 & 79 & 84 & 44 \\
\hline
\end{tabular}

So low indicator in 64 percent directly is reflected in indicators of use of the public and municipal services in an electronic form [11]. At the same time, special attention should be paid to providing access to the Internet resources of sparsely populated administrative entities, urban and rural settlements of the region.

In addition, the Russian authorities, including those in the Volgograd region, should completely abandon paperwork in the framework of the formation of the digital economy by 2024, as described in the proposals of the Center for Strategic Research under the leadership of former Finance Minister A. Kudrin "Transformation of the state system management for successful implementation of development tasks ".

Digital behavior, like the habit of sustainable widespread use of digital technologies in everyday practices, begins to turn from a niche into a dominant one. This allows us to expect the creation of holistic multidimensional ecosystems in the digital economy. Digitalization of large Russian cities is developing rapidly. For the year from the end of 2014 to the end of 2015, the average index of the digital life index has increased almost in half, from 0.38 to 0.55 . Among the leading cities: St. Petersburg and Moscow, which developed faster. Kazan and Novosibirsk took the fourth and fifth places, overtaking Perm, Krasnoyarsk and Samara. The remaining were Volgograd and Voronezh. The most dynamically developing city was Rostov-on-Don [12].

The development of digital technologies leads to the transformation of regional markets, including the financial services market. Ecosystems are created in credit organizations. The process of digitalization of financial services is under the control of the Bank of Russia, which created a sandbox for determining the regulatory field and conducting economic and legal analysis using digital technologies. From July 1, 2018, the Bank of Russia plans to launch a platform for remote identification in banks, which will allow residents of the regions to receive several banking and insurance products. Before using the platform of the marketplace, citizens should visit the bank to submit biometric parameters for storage in the Unified Biometric System [13]. At the same time, it is necessary to provide tools for protecting against cyber-attacks, integrating the elements of cyberresistance into the package of services. Despite the riskiness of the promotion of crypto-currencies in Russia, it is necessary to determine the economic and legal basis for its use.

\section{CONCLUSION}

Based on the analysis, a number of measures can be identified to develop the economic and legal support of the digital economy in the Russian Federation, in general, and the Volgograd region in particular.

First of all, at the federal level, it is necessary to implement the following measures:

- Adoption of the basic federal law "On the digital economy in the Russian Federation", defining the conceptual-categorical apparatus of the digital economy, the principles of state regulation of the digital economy, and the basic infrastructure elements of the digital economy (information infrastructure and security), legal status, responsibility of subjects of legal relations in the digital economy.

- Creation of legal conditions for the formation of a unified digital environment of trust, allowing to provide participants of the digital economy with means of trusted digital distance communications.

- Adoption of the federal law on the implementation of digital technologies in the financial sphere, which regulates: 1) the creation of digital banks; 2) the development of Internet banking, the provision of remote banking and other financial services; 3) the 
transition of the payment system to digital technologies; 4) the digitalization of bank lending; , in order to increase the availability of borrowed funds for the convenient and rapid implementation of financial transactions, avoiding the expensive physical infrastructure, 5) the use of biometric technologies to ensure cial security, 6) cybersecurity (the legal status of a cyber-security mechanism to protect the participants of financial relations), 7) issuing its own digital currency-cryptoruble.

- Amendments to civil legislation, defining a legal mechanism for the protection of intellectual property rights and the results of intellectual activity, including the mechanism for capitalizing the results of intellectual activity.

- Amend the tax legislation aimed at stimulating the development of the digital economy, provide for a special tax regime for subjects of legal relations in the digital economy, and provide tax benefits to companies engaged in the development of modern technologies.

At the regional level, in particular in the Volgograd region, the improvement of the economic and legal regulation of the digital economy is possible through the implementation of activities such as:

- Development and adoption of the main document the program for the development of the digital economy in the Volgograd region until 2024, taking into account the specifics of the region (development of the agro-industrial complex, industrial production), focusing on the creation and development of infrastructure for the use of digital technologies in 2018-2019.

- Creation of working groups, competence centers on the basis of the state treasury of the Volgograd Oblast "Center for Information Technologies of the Volgograd Region", providing development of directions of the digital economy (information infrastructure, security, personnel support) in accordance with the developed activities.

- Development and implementation of the digital project "Smart Region" within the framework of the regional program for the development of the digital economy of the Volgograd region in order to improve the quality, safety of people's lives, ensure a high level of urban environment improvement, create opportunities for business development, facilitate interaction between citizens and organizations with government agencies.

- Establishment of tax incentives for subjects of the digital economy.

- Providing access to broadband Internet for at least $90 \%$ of the population of the Volgograd region until 2020.

- Increase in financial literacy of the population.
In modern conditions, the digitalization of the Volgograd region should be intensified, namely: actively introduce digital technologies into the work of officials and authorities, switch to electronic document management; to develop and implement a fundamentally new digital product that will provide comprehensive information about the region, municipalities.

\section{References}

[1] The Strategy for the Development of the Information Society in the Russian Federation for 2017-2030, approved by Presidential Decree No. 203 of May 9, 2017 [Strategiya razvitiya informatsionnogo obshhestva v Rossijskoj Federatsii na 2017-2030gg, utverzhdennaya Ukazom Prezidenta] - URL: ATP "Consultant Plus"

[2] Rostelecom evaluated the project of digitalization of the Russian economy in 427 billion rubles [ «Rostelekom» ocenil proekt cifrovizacii jekonomiki RF v 427 mlrd. rub] // Digest of the Analytical Center under the Government of the Russian Federation. - URL: http://ac.gov.ru/files/attachment/15109.pdf.

[3] There are eight directions for the development of the Digital Economy in Russia. [Opredeleny vosem' napravlenij razvitija «Cifrovoj jekonomiki v Rossii»] - URL: https://forklog.com/opredeleny-vosem-napravlenijrazvitiya-tsifrovoj-ekonomiki-v-rossii/.

[4] Strategy of social and economic development of the Volgograd region until 2030. [Strategija social'no-jekonomicheskogo razvitija Volgogradskoj oblasti do 2030 goda] - URL: http://economics.volgograd.ru/strategic-planning; The strategy of social and economic development of Volgograd until 2030 - URL: http://www.volgadmin.ru/d/strategy2030/index.

[5] On the approval of the program "Digital Economy of the Russian Federation": Order of the Government of the Russian Federation No. 1632-r of July 28, 2017 [Ob utverzhdenii programmy «Cifrovaja jekonomika Rossijskoj Federacii»: rasporjazhenie Pravitel'stva RF ot 28.07.2017 №1632-r] // SPS "Consultant Plus".

[6] Indicators of the digital economy: 2017. [Indikatory cifrovoj jekonomiki: 2017.] - URL: https://www.hse.ru/ data / $2017 / 08 / 02 / 1173493230 \quad / \quad$ IIO $\% \quad 202017 . \% \quad 20$ Osnovnye $\%$ 20pokazateli\% 20razvitija\% 20cifrovoj\% 20jekonomiki.pdf.

[7] Digital Economy Act. - URL: http://www.legislation.gov.uk/ukpga/ 2017/30/pdfs/ukpga_20170030_en.pdf.

[8] Driving Innovation and Growth in Internet Technology and Launching Universal Access to the Global Economy (DIGITAL AGE) Act of 2017. - URL: https://www.congress.gov/bill/115th-congress/senatebill/449?q=\%7B $\% 22$ search $\% 22 \% 3 \mathrm{~A} \% 5 \mathrm{~B} \% 22$ digital+economy+act $\% 22$ $\% 5 \mathrm{D} \% 7 \mathrm{D} \& \mathrm{r}=1$.

[9] Copyright Office for the Digital Economy Act//https://chu.house.gov/sites/chu.house.gov/files/documents/CODE\% 20 Act $\% 20$ Section $\% 20$ by $\% 20$ Section.pdf.

[10] Indicators of the digital economy: 2017. [Indikatory cifrovoj jekonomiki: 2017.] - URL: https://www.hse.ru/data/2017/08/03/1173503128/IIO\%202017.\%2013. $\% 20$ Osnovnye \%20pokazateli\%20razvit..\%20sub\% 23ektah\% 20Rossijskoj\% 20Federacii.pdf.

[11] Indicators of the digital economy: 2017. [Indikatory cifrovoj jekonomiki: 2017.] $\quad$ URL: https://www.hse.ru/data/2017/08/03/1173503128/IIO\%202017.\%2013. $\% 20$ Osnovnye \%20pokazateli\%20razvit..\%20sub\% 23ektah\% 20Rossijskoj\% 20Federacii.pdf.

[12] The digital life of Russian megacities. [Cifrovaja zhizn' rossijskih megapolisov] https://iems.skolkovo.ru/downloads/documents/SKOLKOVO_IEMS/Re search_Reports/SKOLKOVO_IEMS_Research_2016-11-30_en.pdf.

[13] On Amending Certain Legislative Acts of the Russian Federation: Federal Law of December 31, 2017. №482-Ф3 [O vnesenii izmenenij v otdel'nye zakonodatel'nye akty Rossijskoj Federacii: federal'nyj zakon ot 31 dekabrja 2017g. №482-FZ] - URL: http://www.consultant.ru/document/cons_doc_LAW_286744/ 